\title{
COMMON LAW RIGHTS: BALANCING DOMESTIC AND INTERNATIONAL EXIGENCIES
}

\author{
EIRIK BJORGE ${ }^{1}$
}

\begin{abstract}
The protection of human rights through common law principles and values has a greater potential than has been recognised hitherto. First, the adoption at common law of the proportionality test of interferences with rights shows that, when human rights are at issue, the courts will apply an exigent test, allowing interferences only if, amongst other things, a less intrusive measure could not have been used. Secondly, the principle of legality, along with common law constitutionalism as developed recently by the Supreme Court, now means that there is a common law pendant to the rule in s. 3(1) of the Human Rights Act 1998. Thirdly, in cases where the protection offered by the Act is displaced by obligations under the Charter of the United Nations, there is no displacement of common law rights, which continue to operate. Fourthly, common law rights are more open to the influences of the customary international law of human rights than are Convention rights. These factors combine to mean that the future of common law rights is an auspicious one.
\end{abstract}

KEYWORDS: common law rights; autochthony; proportionality; principle fundamental to the rule of law; implied abrogation; Human Rights Act 1998; Charter of the United Nations; customary international law.

\section{INTRODUCTION}

Whatever the future of the Human Rights Act 1998, an auspicious future lies ahead for domestic protection of fundamental rights through the common law. The present article makes this argument by means of four contentions, the first two of which concern the domestic constitutional backdrop against which common law rights must be understood; the latter two of which concern the international law background against which common law rights are construed and applied. The point is in no way to deprecate the Human Rights Act: it is rather to contribute to bringing common law rights out of the shadow cast by the Act and to make a contribution to redressing the balance of argument in the light of a number of criticisms of common law rights as a sound basis for protecting liberty.

Focusing on exigencies of domestic law, Part II of this article argues, first, that there is more to the so-called normative reach (that is, the number of rights to whose protection the common law is committed) of common law protection of fundamental rights than has been recognised. This part of the article argues that as, in the context of interferences with important rights, the courts apply in effect a proportionality test at common law, debates as to which rights are better protected by the common law have become largely academic. Secondly, Part II of the article argues that the

\footnotetext{
${ }^{1}$ Shaw Foundation Junior Research Fellow, Jesus College, University of Oxford. Address for correspondence: Eirik Bjorge, Jesus College, Turl Street, Oxford OX1 3DW. Email: eirik.bjorge@law.ox.ac.uk. I am grateful for comments by numerous colleagues on presentations of earlier versions of this paper at All Souls College, Oxford, on 7 November 2014, and at the Palais des Nations, United Nations, Geneva, on 4 May 2015. I am grateful also to the numerous colleagues, including the reviewers, who read the final paper and provided me with helpful suggestions.
} 
protective rigour accorded to common law rights has more potential than has been recognised. As will be seen the article thus relies in part on the conceptual apparatus developed by Mark Elliott in his recent and valuable work on human rights and the common law. $^{2}$

Part III, by focusing on exigencies of international law which shape the effectiveness of rights protection by the UK courts, argues that the non-legislative character of common law rights is not as much of an infirmity as has been claimed by some. This proposition is borne out, first, by showing that, unlike the rights protected under the HRA, common law rights are not set aside by other international law obligations, such as the Charter of the United Nations. Secondly, it is argued that common law rights, more easily than Convention rights, can give effect to the rich vein of rights guarantees which are to be found in the customary international law of human rights. Part IV concludes the analysis.

There is a growing literature on the question of common law fundamental rights. ${ }^{3}$ Four particularly incisive notes of caution have been sounded in the scholarship. First, Brice Dickson has come close to writing common law rights off entirely, as in his view rights protection in the United Kingdom has 'internationalized rather than constitutionalized'. ${ }^{4}$ It will be argued in this article that it has been clear for some time that, whether on its own or in parallel with the HRA, the common law has developed its protection of fundamental rights in a way that cannot be deprecated as being no more than a domestic handmaiden to the HRA. ${ }^{5}$

Secondly, Elliott has argued that it would be naïve to suggest that common law rights could seamlessly step in if the HRA were repealed or if the United Kingdom were to resile from the Convention, as the normative reach of the common law has been and would remain, post-HRA, more modest than that of the Convention. In his view the courts' protective commitment to rights which lie at or near the common law's normative core may confer on those rights a degree of legal security approximating to that which is associated with Convention rights under the HRA: but the same cannot in his view be plausibly claimed of the whole range of rights and values acknowledged at common law. ${ }^{6}$ Elliott stresses how the common law has paid particular attention to the right of access to court and the right to freedom of expression. ${ }^{7}$ It could be pointed out that other rights, too, enjoy strong protection at common law; the right not to be tortured, ${ }^{8}$ the right to life, ${ }^{9}$ and the right not to be

\footnotetext{
${ }^{2}$ M. Elliott, 'Beyond the European Convention: human rights and the common law' (2015) 68 C.L.P. 85.

${ }^{3}$ P. Sales, 'Rights and fundamental rights in English law' (2016) 75 C.L.J. 86, 89-102; P. Craig, UK, EU and Global Administrative Law: Foundations and Challenges (Cambridge 2015), 271-85; Elliott, 'Beyond the European Convention'; S. Sedley, Lions under the Throne (Cambridge 2015), 193-208; R. Clayton, 'The Empire strikes back' [2015] P.L. 3; B. Dickson, Human Rights in the UK Supreme Court (Oxford 2013) 20-9; M. Fordham, 'Common law rights' [2011] J.R. 14; T.R.S. Allan, The Sovereignty of Law: Freedom, Constitution and Common Law (Oxford 2013), 88-132 \& 168-207; J. Beatson and others, Human Rights: Judicial Protection in the United Kingdom (London 2008) 2-18.

${ }^{4}$ Dickson, Human Rights, 20-36, esp. p. 31.

${ }^{5}$ e.g. Kennedy $v$ Charity Commission (Secretary of State for Justice and Others Intervening) [2014] UKSC 20; [2014] 2 W.L.R. 808; A. v BBC [2014] UKSC 25; [2014] 2 All E.R. 1037 at [56]-[57] (Lord Reed); R. (Osborn) v Parole Board [2013] UKSC 61; [2014] A.C. 1115.

${ }^{6}$ Elliott, 'Beyond the European Convention', p. 116.

${ }^{7}$ ibid. p. 88. Also: Clayton, 'Empire strikes back'; Dickson, Human Rights, 20-9.

${ }^{8}$ A. (No. 2) v Secretary of State for the Home Department [2005] UKHL 71; [2006] 2 A.C. 221 at [51] (Lord Bingham); Matthew v State of Trinidad and Tobago [2005] 1 A.C. 433 at [12].

${ }^{9}$ R. $v$ Home Secretary, Ex p. Bugdaycay [1987] A.C. 514, 531; R. (Amin) v Secretary of State for the Home Department [2003] UKHL 51; [2004] 1 A.C. 653 at [16].
} 
discriminated against ${ }^{10}$ could be thought to be good candidates in that regard. Focusing on the potentially differing level of protection offered to different rights may be fruitful; but, given the approach that the Supreme Court takes to the protection of rights under the HRA and at common law, it is arguably more useful to focus instead on the systemic feature which is the test that the courts apply in relation to interferences with the right at issue. Increasingly, common law rights and HRA rights alike are protected through judicial reliance on the proportionality inquiry (or a rationality inquiry which amounts in substance to the same test) which the courts will apply in cases where it is alleged by a claimant that a fundamental right is at issue and that the government has made unacceptable inroads into that right. As will be shown, this test is no less rigorous at common law than it is under the HRA.

Thirdly, Richard Clayton has argued that the principle of legality cannot be held to match the interpretative injunction of s. 3(1) of the HRA, and that the protection of common law rights is therefore in the final analysis toothless as compared to the rights protection offered by the HRA. ${ }^{11}$ The intricacies of this argument will be explained more fully Part II B; suffice it here to say that by reason of cases such as Simms, ${ }^{12}$ Thoburn, ${ }^{13}$ and HS2, ${ }^{14}$ if it did not already when Simms was handed down, the principle of legality now emulates the strong interpretative injunction of s. 3(1).

Fourthly, Paul Craig has pointed up the apparent judicial desire, within UK public law, to assert some degree of independence in the relations between the United Kingdom and other legal orders. He has termed this autochthony, which connotes the descriptive and normative ideal of attachment to indigenous or native values over exogenous ones. ${ }^{15}$ In this connection Craig brings out two attractive features of autochthony within the human rights field: ${ }^{16}$ first, the fact that the UK courts will in certain cases, on the basis of their own conceptions of human rights law, make their own interpretation of Convention rights; ${ }^{17}$ and, secondly, that the UK courts have in recent times drawn much more on the resources of the common law than it did in the first fifteen years of the Human Rights Act. ${ }^{18}$ Nonetheless Craig warns against taking the autochthonous approach too far, as it might manifest itself in distrust of the 'other', whether the foreign court, the foreign person, or the minority living in one's own land. Against this background, the present article endeavours to contribute to making out an autochthonous, or common law based, approach to fundamental rights protection that fully benefits from the positive desire for indigenous values, without falling prey to the dangers isolated by Craig. This will be highlighted especially in Part III B, which analyses the way in which the emphasis of autochthonous

\footnotetext{
${ }^{10}$ Matadeen \& Others v MGC Pointu \& Others (Mauritius) [1998] UKPC 9; [1999] 1 A.C. 98 at [8][11] (Lord Hoffmann); AXA General Insurance Ltd v H.M. Advocate [2011] UKSC 46, [2012] 1 A.C. 868 at [97] (Lord Mance).

${ }^{11}$ Clayton, 'Empire strikes back', p. 12.

${ }^{12}$ Ex p. Simms [2000] 2 A.C. 115.

${ }^{13}$ Thoburn v Sunderland City Council [2002] EWHC 195 (Admin.); [2003] Q.B. 151.

${ }^{14} R$. (on the application of HS2 Action Alliance Ltd.) $v$ Secretary of State for Transport [2014] UKSC 3; [2014] 1 W.L.R. 324.

${ }^{15}$ Craig, UK, EU and Global Administrative Law, p. 272.

16 ibid, 273-80.

${ }^{17}$ Also: R. Clayton, 'Smoke and mirrors: the Human Rights Act and the impact of the Strasbourg case law' [2012] P.L. 639; E. Bjorge, 'The courts and the ECHR: a principled approach to the Strasbourg jurisprudence’ (2013) 72 C.L.J. 289.

${ }^{18}$ See note 5 above.
} 
fundamental rights protection in the common law potentially opens UK law up to influences from general international law.

\section{THE INTERNAL EXIGENCIES OF COMMON LAW CONSTITUTIONALISM}

\section{A. Common law rights in cases involving executive action}

In a number of those leading cases regarding the HRA in which the allegedly rights offending measure was not contained in legislation and the claimant won on an argument based on Convention rights, the result is likely today to have been the same had the case been run instead only on common law grounds.

This proposition is borne out by the important case of Bank Mellat (No. 2), ${ }^{19} \mathrm{a}$ rights case involving, on the one hand, the rights of the individual and, on the other, the interest of the state in combating threats to national security, that is, an area of the law where traditionally the courts have been reticent to intervene, whatever their legal basis for controlling executive action. ${ }^{20}$

Bank Mellat (No. 2) concerned the protection of ordinary property rights, in that it bore on the lawfulness of certain measures which - by reason of suspicions that Bank Mellat was connected with Iran's nuclear and ballistic missiles programmes stipulated that all persons operating within the financial sector in the United Kingdom must not enter into or continue with any transaction or business relationship with the bank. The claimant argued that the measures were in breach both of the HRA and of the common law.

Traditionally, both at common law and under the ECHR, the protective rigour accorded to the right peacefully to enjoy one's property has been less strong than is the case with other rights. As Lord Hoffmann put it in Reprotech, ${ }^{21}$ under the hierarchy of rights protection in the United Kingdom, 'for example, the individual's right to a home is accorded a high degree of protection', 'while ordinary property rights are in general far more limited by considerations of public interest'. ${ }^{22}$ What Bank Mellat (No. 2) says about the protection of property rights, therefore, could be thought to apply a fortiori in respect of other rights. The same could be said of Ahmed, ${ }^{23}$ another case concerning ordinary property rights, where too the Supreme Court went to great lengths to ensure that ordinary property rights were protected: that case will be dealt with below in Part III A.

At issue in Bank Mellat (No. 2) was s. 62 of the Counter-Terrorism Act 2008, which gave effect to Schedule 7, which in turn empowered the Treasury to make a direction by statutory instrument in situations specified in para. 1, involving certain categories of 'risk' - of which nuclear proliferation was one - associated with a foreign country outside the European Economic Area. Bank Mellat had been singled out from other Iranian banks as it had been identified as having assisted Iran's weapons programmes by providing banking and financial services to entities involved with them. ${ }^{24}$ Schedule 7 was not a sanctions regime; its purpose was rather directly to

\footnotetext{
${ }^{19}$ Bank Mellat (No. 2) [2013] UKSC 39; [2014] A.C. 700. See also Ahmed v H.M. Treasury [2010] UKSC 2; [2010] 2 A.C. 534.

${ }^{20}$ Generally: T. Poole, Reason of State: Law, Prerogative and Empire (Cambridge 2015), $275-85$.

${ }^{21}$ R. (Reprotech (Pebsham) Ltd.) v East Sussex C.C. [2002] UKHL 8; [2003] 1 W.L.R. 348.

${ }^{22}$ Citing $R$. (Alconbury Developments Ltd.) v Secretary of State for the Environment, Transport and the Regions [2001] UKHL 23; [2003] 2 A.C. 295.

${ }^{23}$ Ahmed v H.M. Treasury [2010] UKSC 2; [2010] 2 A.C. 534.

${ }^{24}$ Bank Mellat (No. 2) [2013] UKSC 39; [2014] A.C. 700 at [12].
} 
restrict the availability of financial services which contributed to the relevant risk. The trial judge and the Court of Appeal had both found the impugned measures to be lawful. The essential question in the case was whether the interruption of commercial dealings with Bank Mellat in the United Kingdom's financial markets bore some rational and proportionate relationship to the statutory purpose of hindering the pursuit by Iran of its weapons programmes. ${ }^{25}$

Lord Sumption began his review of the measures at issue by observing that the requirements of rationality and proportionality, as applied to decisions engaging the human rights of claimants, 'inevitably overlap'. ${ }^{26}$ That is an important judicial determination. It seems to amount not only to saying that the application of common law proportionality in rights cases overlaps with ECHR proportionality, but also that the application of common law rationality to rights cases, too, overlaps with the proportionality inquiry mandated by ECHR law. ${ }^{27}$ This is reinforced by the fact that the cases to which Lord Sumption referred as authorities for this proposition were an admixture of cases decided on HRA and common law grounds. In its context, it also shows that the claimant's case was decided both on HRA and common law grounds.

A similar point has been made in other cases too, such as Pinnock (No 2), ${ }^{28}$ which concerned demoted tenancies and the right to private life. In connection with the test to be applied, rationality or proportionality, Lord Neuberger in Pinnock (No 2) cited Lord Greene M.R. in Cumming $v$ Danson ${ }^{29}$ to the effect that 'reasonableness involves the trial judge "tak[ing] into account all the relevant circumstances ... in ... a broad common-sense way"', determining against this background that it did not matter much whether the case was resolved on proportionality grounds or reasonableness: 'It therefore seems highly unlikely, as a practical matter, that it could be reasonable for a court to make an order for possession in circumstances in which it would be disproportionate to do so under article 8. 30

But whereas Pinnock (No. 2) concerned the individual's right to a home, Bank Mellat (No. 2) was, as mentioned above, concerned with ordinary property rights. That is why it is of interest that the Supreme Court applied such an exigent test as to the interference with the right at issue. Lord Sumption in Bank Mellat (No. 2) set out the by now familiar four step proportionality test to be applied, which consisted of:

an exacting analysis of the factual case advanced in defence of

the m easure,

in order to determine (i) whether its objective is sufficiently important to justify the limitation of a fundamental right; (ii) whether it is rationally connected to the objective; (iii) whether a less intrusive measure could have been used; and (iv) whether, having regard to these matters and severity of the consequences, a fair balance has been struck between rights of the individual and the interests of the community. ${ }^{31}$

As will by now be plain, it is difficult to spot in this jurisprudence anything suggesting that the ordinary property rights in issue in Bank Mellat (No. 2) are now 'far more limited by considerations of public interest' than is the case with other

\footnotetext{
25 ibid at [19].

${ }^{26}$ ibid at [20].

27 See on this P. Craig, 'The nature of rationality review' (2013) 66 C.L.P. 131.

${ }^{28}$ Manchester City Council v Pinnock (Nos. 1 and 2) [2010] UKSC 45; [2011] 2 A.C. 104.

${ }^{29}$ Cumming v Danson [1942] 2 All E.R. 653, 655.

${ }^{30}$ Manchester City Council v Pinnock (Nos. 1 and 2) [2010] UKSC 45; [2011] 2 A.C. 104 at [56].

${ }^{31}$ Bank Mellat (No. 2) [2013] UKSC 39; [2014] A.C. 700 at [20].
} 
rights. $^{32}$

In the circumstances of Bank Mellat (No. 2) it was only the third question, whether a less intrusive measure could have been used, that came to a head, as it had been suggested that a measure would be disproportionate if a more limited measure was capable of achieving the objective. This was rephrased by Lord Sumption in the following way: '[t]he question is whether a less intrusive measure could have been used without unacceptably compromising the objective'. ${ }^{33}$ This mirrors the - very exigent - test set out by the Grand Chamber of the European Court of Human Rights in Nada $v$ Switzerland, a case concerning Article 8 rights: 'for a measure to be regarded as proportionate and as necessary in a democratic society, the possibility of recourse to an alternative measure that would cause less damage to the fundamental right at issue whilst fulfilling the same aim must be ruled out. ${ }^{34}$

Lord Sumption acknowledged that the issues to be determined lay within the area of foreign policy and national security (areas in which the courts have traditionally been careful not to adopt too searching a review of executive action) ${ }^{35}$ and that the potential consequences of nuclear proliferation were quite serious enough to justify a precautionary approach. Nonetheless he saw two difficulties with the conclusion of the courts below: first, it did not explain, let alone justify, the singling out of Bank Mellat, if (as both courts below had agreed) the problem was a general problem of international banking; secondly, the justification for the directive which they had found was not the one which ministers had advanced when laying the direction before Parliament (it was in fact in some respects inconsistent with it). ${ }^{36}$

Citing A ('Belmarsh'), ${ }^{37}$ Lord Sumption observed that: '[a] measure may respond to a real problem but nevertheless be irrational or disproportionate by reason of its being discriminatory in some respect that is incapable of objective justification.' His Lordship then cited Lord Hope's words in $A$ to the effect that 'the distinction raises an issue of discrimination, ... as the distinction is irrational, it goes to the heart of the issue about proportionality also. ${ }^{38}$ In $A$ only foreign potential terrorists had been detained; the threat from potential terrorists who were UK nationals had been thought to be adequately addressed without depriving them of their liberty indefinitely without trial. No reason had been adduced why the same should not be true of foreign nationals. As the Home Secretary in A had not sufficiently demonstrated why the foreign potential terrorists should be singled out, so the Home Secretary in Bank Mellat (No. 2) had failed to show why Bank Mellat should be singled out, no convincing reason having been adduced as to why the measures should not also have applied to the other banks.

It is difficult to conceive of Bank Mellat (No. 2) as being somehow a low water mark; instead it serves as an exemplification of how, through reliance on a test which in effect amounts to proportionality at common law, ${ }^{39}$ the courts give strong protection even to rights which have been considered to be given no more than weak

\footnotetext{
${ }^{32}$ R. (Reprotech (Pebsham) Ltd.) v East Sussex C.C. [2002] UKHL 8; [2003] 1 W.L.R. 348 (Lord Hoffmann).

33 ibid at [20].

${ }^{34}$ Nada v Switzerland (2013) 56 E.H.R.R. 18 at [167]; Bjorge, Courts as Faithful Trustees, 156-7.

${ }^{35}$ Poole, Reason of State; C. McLachlan, Foreign Relations Law (Cambridge 2014).

${ }^{36}$ Bank Mellat (No. 2) [2013] UKSC 39; [2014] A.C. 700 at [22]-[23].

${ }^{37}$ A. v Secretary of State for the Home Department ('Belmarsh') [2004] UKHL 56; [2005] 2 A.C. 68.

${ }^{38}$ Bank Mellat (No. 2) [2013] UKSC 39; [2014] A.C. 700 at [25]; A. v Secretary of State for the Home Department ('Belmarsh') [2004] UKHL 56; [2005] 2 A.C. 68 at [132].

39 The phrase 'proportionality at common law' is taken from Pham v Secretary of State for the Home Department [2015] UKSC; [2015] 1 W.L.R. 1591 at [107] (Lord Sumption).
} 
protection by the common law.

Although the Human Rights Act introduced a new element into the constitutional law of the United Kingdom, and entails some adjustment of the respective constitutional roles of the courts, the executive, and the legislature, the Act did not, however, effect any transformative changes of the separation of powers. ${ }^{40}$ As Lord Sumption put it in Carlile: '[t]he Human Rights Act 1998 did not abrogate the constitutional distribution of powers between the organs of the state which the courts had recognized for many years before it was passed. ${ }^{41}$

Against that background, it is worth pointing up that common law reasoning (which obviously drew on pre-HRA traditions) played an important part in $A$. Certainly, Lord Bingham accepted ${ }^{42}$ that in urging the fundamental importance of the right to personal freedom, as a part of their proportionality argument, the appellants in $A$ were able to draw 'on the long libertarian tradition of English law, dating back to chapter 39 of Magna Carta 1215, given effect in the ancient remedy of habeas corpus, declared in the Petition of Right 1628, upheld in a series of landmark decisions down the centuries and embodies in the substance and procedure of the law to our won day'. 43 '[F]or all of the reasons they gave', continued Lord Bingham, amongst which were the reference to the guarantees of the common law, the appellants' proportionality challenge was 'sound'. ${ }^{44}$ Similarly, Lord Rodger observed that by checking whether in the context of the case the impugned measure was strictly required by the exigencies of the situation, 'British courts are performing their traditional role of watching over the liberty of everyone within their jurisdiction'. ${ }^{45}$ Baroness Hale referred to the fact that the common law does not allow indefinite detention at the behest of the executive. ${ }^{46}$ Without the HRA there would, in $A$, have been no declaration of incompatibility, of course; but, as pointed out by Trevor Allan, a similar result could arguably have been reached by way of interpretation. ${ }^{47}$ The interpretative presumption referred to as the principle of legality is dealt with below in part II(b).

It is not fanciful to speculate that the Human Rights Act may have played the role of bringing back to light fundamental freedoms and principles which have been long overlooked in the common law. Indeed the very fact of the existence of the Human Rights Act may in certain respects have exerted an influence on the common law. Thus the Supreme Court in Montgomery observed that, '[u]nder the stimulus of the Human Rights Act 1998, the courts have become increasingly conscious of the extent to which the common law reflects fundamental values'. ${ }^{48}$ According to its long title, the HRA is an 'Act to give further effect to rights and freedoms guaranteed

\footnotetext{
${ }^{40} R$. (on the application of Nicklinson and another) $v$ Ministry of Justice [2014] UKSC 38; [2015] A.C. 657 at [296] (Lord Reed); $R$. (on the application of S.G. and others) $v$ Secretary of State for Work and Pensions [2015] UKSC 16, [2015] W.L.R. 159 at [92] (Lord Reed).

${ }^{41}$ R. (on the application of Lord Carlile of Berriew Q.C.) v Secretary of State for the Home Department [2014] UKSC 60; [2015] A.C. 945 at [28]. Also: Ex p. Simms [2000] 2 A.C. 115, 131-2 (Lord Hoffmann).

${ }^{42}$ A. $v$ Secretary of State for the Home Department [2004] UKHL 56; [2005] 2 A.C. 68 at [36] \& [43].

43 ibid at [36].

44 ibid at [43].

45 ibid at [178].

46 ibid at [222].

${ }^{47}$ See Allan, Sovereignty of Law, 114-19, drawing, in part, on J. Finnis, 'Nationality, Alienage and Constitutional Principle’ (2007) 123 L.Q.R. 417, 430-5.

${ }^{48}$ Montgomery v Lankashire Health Board [2015] UKSC 11; [2015] A.C. 1430 at [80] (Lord Kerr \& Lord Reed).
} 
under the European Convention on Human Rights'; ${ }^{49}$ indeed, according to the terms of s. 11(a), entitled Safeguard for existing human rights, the Act is without prejudice to 'any right or freedom conferred by or under any law having effect in any part of the United Kingdom'. ${ }^{50}$

Whilst it is obviously possible to repeal the HRA, it is not possible to expunge from the law reports the judgments in which the HRA has done its work, ${ }^{51}$ and the indelible imprint it has left on the common law. According to a line of Tennyson's, which received judicial imprimatur in A $v$ Secretary of State for the Home Department (No. 2), ${ }^{52}$ in the common law 'Freedom slowly broadens down, from precedent to precedent'. ${ }^{53}$ In other words, it is difficult to imagine that the level of common law protection a right has gained at a certain point in time can later diminish.

Once it is established, as it now is in the light of cases such as Bank Mellat (No. 2), Pinnock (No. 2), and A, that the requirements of common law proportionality in rights cases and HRA proportionality 'inevitably overlap', ${ }^{54}$ it is not really necessary to break down to the various rights the level of protection offered by the common law. The common law will protect fundamental rights through the operation of the four stage test set out by Lord Sumption in Bank Mellat, a test which matches even the least intrusive means test crystallised by the European Court of Human Rights. On this approach, even the areas of the law which traditionally was accorded the weakest protection - ordinary property rights - now enjoy strong protection.

\section{B. Cases involving primary legislation: the principle of legality matches s. 3(1) HRA}

By enacting s. 3 of the HRA, ${ }^{55}$ Parliament directed the courts to interpret legislation in a way which is compatible with Convention rights. ${ }^{56}$ This is the case even where such interpretation involves departing from the 'unambiguous meaning the legislation would otherwise bear', or the 'legislative intention ... of the Parliament'. ${ }^{57}$ As, however, Lord Steyn observed in Anderson: 'Section 3(1) is not available where the suggested interpretation is contrary to express statutory words or is by implication necessarily contradicted by the statute. ${ }^{58}$ Does this strong duty on the part of the courts now apply equally strongly to common law rights outside the scope of the Human Rights Act?

In connection with what we would today term fundamental common law rights, it has long been clear that, as Lord Diplock observed in Hoffman-La Roche,

\footnotetext{
${ }^{49}$ Emphasis added.

${ }^{50}$ Bjorge, Courts as Faithful Trustees, 109-10.

51 Though, of course, legislation has at times been deleted from the statute book; this was the case with the republican legislation of the Long Parliament, from the period 1640-60, which was removed from the definitive edition of D Pickering (ed), Statutes at Large (Cambridge 1763): Sedley, Lions under the Throne, 83-4.

${ }^{52}$ A. v Secretary of State for the Home Department (No 2) [2005] UKHL 71; [2006] 2 A.C. 221 at [152] (Lord Carswell).

${ }^{53}$ You Ask Me, Why (1842), verse iii.

${ }^{54}$ Bank Mellat (No. 2) [2013] UKSC 39; [2014] A.C. 700 at [20] (Lord Sumption).

${ }^{55}$ s. 3(1) provides: 'So far as it is possible to do so, primary legislation and subordinate legislation must be read and given effect in a way which is compatible with the Convention rights.'

${ }^{56}$ R. Ekins \& P. Sales, 'Rights-consistent interpretation and the Human Rights Act 1998' (2011) 127

L.Q.R. 217.

${ }^{57}$ Ghaidan v Godin-Mendoza [2004] UKHL 30; [2004] 2 A.C. 557 at [30] (Lord Nicholls); Sheldrake v Director of Public Prosecutions [2005] 1 A.C. 264 at [24] (Lord Bingham).

${ }^{58} R$. (on the application of Anderson) $v$ Secretary of State for the Home Department [2002] UKHL 46; [2003] 1 A.C. 387 at [59] (Lord Steyn); Ekins \& Sales, 'Rights-consistent interpretation', 230-2.
} 
there are certain constructions of an act against which 'the courts lean very heavily' ${ }^{59}$ It is by now axiomatic that, according to the principle of legality, legislation will not be held to allow an interference with a fundamental common law right unless this has been expressly sanctioned by Parliament. ${ }^{60}$ The principle is also known as the Simms principle, as Lord Hoffmann in the eponymous case cast the principle in a particularly attractive form: '[i]n the absence of express language or necessary implication to the contrary, the courts ... presume that even the most general words were intended to be subject to the basic rights of the individual. ${ }^{61}$ Writing extra-judicially, Laws L.J. has observed about the principle of legality that "rights protected by the common law could not be abrogated by statute save by crystal clear provisions leaving no room for doubt as to what the legislative intention was'. ${ }^{62}$ 'Crystal clear' is also the formulation relied on by the Supreme Court. ${ }^{63}$ The principle of legality is thus a far reaching principle of common law rights protection. In Simms and in Wilkinson Lord Hoffmann seemed to equiparate the principle of legality and s. 3(1). ${ }^{64}$ It will be shown that the principle of legality does indeed match s. 3(1).

Before that is done, however, it is necessary first to say something about what will and what will not in the first place be considered to the fundamental common law rights, and who, in principle, makes this determination. In seeking to set out a methodology for the identification of the existence and scope of common law rights, Sir Philips Sales has suggested that the courts should identify a fundamental right or interest for the purposes of the principle of legality only 'if it is plausible to infer that Parliament as a collective body itself recognises such a right or interest and may thus be taken to have legislated on the assumption that it applies' ${ }^{65} \mathrm{He}$ also observed that '[i]f a fundamental right is identified clearly in advance of the act of legislating, it is plausible to infer that, when Parliament legislated, it meant to do so taking that right into account without needing to say so' ${ }^{66}$

It is worth remembering, however, that the principle of legality, by offering judicial protection to certain fundamental rights and principles, is no more than the constitutional variant of the age-old rule according to which an affirmative statute does not take from the common law (statutum affirmativum non derogat communi legi). As Coke put it, 'a statute made in the affirmative, without any negative expressed or implied, does not take away the common law' ${ }^{67}$ The principle has later been reaffirmed by the courts time and again. ${ }^{68}$ In Rottman Lord Hutton cast it in the following terms: 'It is a well-established principle that a rule of the common law is

\footnotetext{
${ }^{59}$ Hoffmann-La Roche \& Co Ltd v Secretary of State for Trade and Industry [1975] A.C. 295, 366.

${ }^{60}$ P. Craig, 'Constitutional and Non-Constitutional Review' (2001) 54 C.L.P. 147, 166; R. (on the application of Evans) v Attorney General [2015] UKSC 21; [2015] A.C. 1787 at [56]-[59] (Lord Neuberger).

${ }^{61}$ Ex p. Simms [2000] 2 A.C. 115, 131.

62 J Laws, 'Constitutional guarantees' (2008) 29 S.L.R. 1, 8.

${ }^{63} R$. (on the application of Evans) v Attorney General [2015] UKSC 21; [2015] A.C. 1787 at [56]-[58] \& [90] (Lord Neuberger).

${ }^{64}$ Ex p. Simms [2000] 2 A.C. 115, 132; R. (Wilkinson) v Inland Revenue Commissioners [2005] UKHL 30; [2005] 1 W.L.R. 1718 at [17]. Also: Ghaidan $v$ Godin-Mendoza [2004] UKHL 30; [2004] 2 A.C. 557 at [104] (Lord Rodger); Allan, Sovereignty of Law, 168-9

${ }^{65}$ Sales, 'Rights and fundamental rights', p. 99.

66 ibid p. 92.

${ }^{67}$ E. Coke, Institutes of the Laws of England 17th ed. (London 1817), p. 200.

68 e.g. Black-Clawson International Ltd. v Papierwerke Waldhof-Aschaffenburg A.G. [1975] AC 591, 614 (Lord Reid); London Borough of Islington v UCKAC \& Another [2006] EWCA (Civ.) 340; [2006] 1 W.L.R. 1303 at [28] (Dyson L.J.); Revenue and Customs Commissioners v Total Network S.L. [2008] UKHL 19; [2008] 1 A.C. 1174 at [130] (Lord Mance).
} 
not extinguished by a statute unless the statute makes this clear by express provision or by clear implication. ${ }^{69}$ It has never been suggested that there is a role to be played in this connection by inferences as to whether or not Parliament recognised the existence in the background of the common law rules at issue. It seems that Sales' point would, by parity of reasoning, mean that only if Parliament as a collective body itself recognised the common law rule or rules at issue could it be taken to have legislated on the assumption that it or they continued to operate. That does not seem to be an attractive rule.

There is a difference between legislation and interpretation: Sales' model goes far in effectively making both of those activities attributable to Parliament. Such a departure seems to be at variance with the constitution in at least three ways. First, the unwritten British constitution, as Lord Diplock classically observed in Duport Steels $L t d$., 'is firmly based upon the separation of powers; Parliament makes the laws, the judiciary interpret them'. ${ }^{70}$

Secondly, and related to the first point, questions of upholding rights, for example rights of vulnerable minorities as against the power of the majority (the latter of which is likely to be well represented at any one time in Parliament), is squarely the constitutional responsibility of the courts. ${ }^{71}$

Thirdly, there are differences between the branches of government as regards their expertise. ${ }^{72}$ The courts are well placed to determine, through their reliance on the common law method, whether or not a right or interest is protected at common law, and then to isolate and delineate those rights or interest for the purposes of the principle of legality. The role of Parliament under the principle of parliamentary sovereignty is preserved in that Parliament can, if it elects to use language of crystalline clarity, expunge such common law rights or principles as it sees fit. ${ }^{73}$ In other words, when they decide whether or not elements of common law operate in the background - protecting fundamental rights or other aspects of the constitutional dispensation - the courts do what they have always done; they ascertain, through an analysis of 'a multitude of particularized prior decisions', ${ }^{74}$ whether or not such elements of the common law obtain. For all these reasons, the existence and reach of fundamental rights protected at common law are found by the courts in the common law, not through inferences as to what Parliament as a collective body would or would not recognise as a common law right.

We can then return to the equiparation of the principle of legality and s. 3(1) HRA. The argument that the principle of legality should be seen to match s. 3(1) has been criticised in the literature. Clayton has been notable for arguing powerfully against such a development; in his view a modified principle of legality has no legal pedigree, unlike the long established principle set out in Simms. ${ }^{75}$

This argument does not withstand scrutiny. To say that new common law principles cannot be allowed to crystallise, whereas old and by now established ones have a venerable pedigree, is to overlook the fact that by necessity the old ones, too, came from somewhere. It is no doubt true that the common law exhibits, as Sedley

\footnotetext{
${ }^{69} R$. (on the application of Rottman) v Commissioner of Police for the Metropolis [2002] UKHL 20; [2002] 2 A.C. at 692 at [75].

${ }^{70}$ Duport Steels Ltd. $v$ Sirs [1980] 1 W.L.R. 142, 157B; also: 169 (Lord Scarman).

${ }^{71} \operatorname{Re} G$ (Adoption: Unmarried Couple) [2008] UKHL 38, [2009] 1 A.C. 173 at [48] (Lord Hope).

72 e.g. R. (J.S.) v Secretary of State for Work and Pensions [2015] UKSC 16; [2015] 1 W.L.R. 1449 at [92]-[93] (Lord Reed).

73 cf. e.g. Moohan v The Lord Advocate [2014] UKSC 67, [2014] W.L.R. 544 at [35] (Lord Hodge).

${ }^{74}$ F.R. Kellogg, 'Law, morals and Justice Holmes’ (1986) 69 Judicature 214, 217.

${ }^{75}$ Clayton, 'Empire strikes back’, p. 12.
} 
L.J. once classically put it, a perennial need 'to appear not to be doing anything for the first time'. ${ }^{76}$ This is indubitably an important feature of the common law; it might be thought to be second only to the ability of the common law to adapt and to change to the exigencies of new circumstances.

At all events, the necessary pedigree does in point of fact obtain: and the adaptation has already been effected. For Simms, ${ }^{77}$ Thoburn, ${ }^{78}$ and $H S 2^{79}$ combine to bear out the proposition that there already exists a duty on the part of the courts, so far as possible, to interpret legislation in a way which is compatible with fundamental common law rights. The convergence between Simms and Thoburn is plain: Sir John Laws made the point that the adjustment in Thoburn 'of the doctrine of implied repeal really does no more than replicate an approach already taken by the courts to common law constitutional principles' in cases such as Simms. ${ }^{80}$ More recently Craig has pointed to the convergence between the principle making up the backbone of Simms and the principle on which the Supreme Court relied in HS2. ${ }^{81}$ Nonetheless, the relationship between the three judgments requires some amplification.

The Supreme Court in HS2 ${ }^{82}$ made it clear beyond peradventure that if a common law fundamental right rises to the level of being a principle 'fundamental to the rule of law', then it will, in common with constitutional statutes, be immune from implied legislative abrogation. ${ }^{83}$ It seems that one example of such a fundamental principle is the 'constitutional distribution of powers between the organs of the state' which the courts recognised for many years before the HRA was passed, the effect of which recognition was that, failing sufficiently clear language in the HRA, the principle continues to operate unabrogated at common law. ${ }^{84}$

In HS2 the Supreme Court developed Thoburn, ${ }^{85}$ by introducing a wider idea of constitutional principles, which might be expressed or reflected in statutory provisions, or might be developed judicially through the common law. What concerns us in this connection are common law principles. The implied abrogation of such principles, like the possibility of implied repeal of a constitutional statute, can be countenanced only if the implication is incontrovertible. This is similar to what was suggested by Laws L.J. in Thoburn: in the absence of express abrogation - or words which are crystal clear - there would have to be words in the later statute 'so specific that the inference of an actual determination to effect the result contended for was irresistible'. ${ }^{86}$ This approach also coheres with Evans, where the Supreme Court, building on celebrated cases such as $R . v$ Cheltenham Commissioners ${ }^{87}$ and Anisminic, ${ }^{88}$ made plain its ready willingness to take serious the principle of legality in

\footnotetext{
${ }^{76}$ Douglas \& Others v Hello! Ltd. [2001] Q.B. 967; [2001] 2 W.L.R. 992, 997 (Sedley L.J.).

${ }^{77}$ Ex p. Simms [2000] 2 A.C. 115.

${ }^{78}$ Thoburn v Sunderland City Council [2002] EWHC 195 (Admin.); [2003] Q.B. 151.

${ }^{79} R$. (on the application of HS2 Action Alliance Ltd) $v$ Secretary of State for Transport [2014] UKSC

3; [2014] 1 W.L.R. 324.

${ }^{80}$ J Laws, ‘Constitutional guarantees', p. 8.

${ }^{81}$ P. Craig, 'Constitutionalising constitutional law: HS2’ [2014] P.L. 373, 387.

${ }^{82} R$. (on the application of HS2 Action Alliance Ltd) $v$ Secretary of State for Transport [2014] UKSC

3; [2014] 1 W.L.R. 324.

83 ibid at [207] (Lord Neuberger \& Lord Mance).

${ }^{84}$ R. (on the application of Lord Carlile of Berriew Q.C.) $v$ Secretary of State for the Home Department [2014] UKSC 60; [2015] A.C. 945 at [28] (Lord Sumption); see notes 40-41 above.

${ }^{85}$ Thoburn v Sunderland City Council [2002] EWHC 195 (Admin.); [2003] Q.B. 151.

${ }^{86}$ Thoburn v Sunderland City Council [2002] EWHC 195 (Admin.); [2003] Q.B. 151 at [63]; Craig, 'Constitutionalising constitutional law', p. 386.

${ }^{87}$ R. v Cheltenham Commissioners (1841) 1 Q.B. 467, 474 (Lord Denman C.J.).

${ }^{88}$ Anisminic Ltd. v Foreign Compensation Commission [1969] 2 A.C. 147, 170 (Lord Reid).
} 
relation not so much to a fundamental right as to a fundamental principle of the common law. ${ }^{89}$

To compare the two tests: common law rights can be abrogated when there are words in the statute which are 'so specific that the inference of an actual determination to effect' an abrogation of the common law right at issue is 'irresistible'. ${ }^{90}$ Convention rights, on the other hand, can under s. 3(1) be abrogated only when 'express statutory words' are to that effect, or the interpretation abrogating the Convention right at issue follows by necessary implication. ${ }^{91}$ If there is any clear blue water at all between these two tests, it is likely to be so little as hardly to distinguish the two approaches from each other.

In connection with the pedigree of such a muscular principle of legality, it is worth mentioning also that a similar principle to the principle exists in international law, where it was classically enunciated by the International Court of Justice in ELSI, ${ }^{92}$ and the Permanent Court of International Justice in River Oder. ${ }^{93}$ This principle of international law was recently given a remit very similar to that of s. 3(1) of the HRA by the Grand Chamber of the European Court of Human Rights in AlJedda $v$ United Kingdom ${ }^{94}$ and Nada $v$ Switzerland. ${ }^{95}$ In Al-Jedda, the Grand Chamber interpreted language in United Nations Security Council Resolution 1546, which provided that 'the multilateral force shall have the authority to take all necessary measures to contribute to the maintenance of security and stability in Iraq in accordance with the letters annexed to this resolution' ${ }^{96}$ One of the annexed letters included mention of 'internment where this is necessary for imperative reasons of security'. The Grand Chamber nonetheless held that: 'there must be a presumption that the Security Council does not intend to impose any obligation on Member States to breach fundamental principles of human rights'. ${ }^{97}$

If the language to be interpreted in Al-Jedda could be thought to be vague enough to put Al-Jedda on all fours with the traditional Simms principle rather than the reinforced Simms principle for which this article argues, that was plainly not the case in Nada $v$ Switzerland..$^{98}$ There the language of the apposite Security Council Resolution, in relation to Al-Qaeda, admitted of no doubt whatever: the respondent

\footnotetext{
${ }^{89} R$. (on the application of Evans) $v$ Attorney General [2015] UKSC 21; [2015] A.C. 1787 at [51]-[59] (Lord Neuberger); T.R.S. Allan, 'Law, democracy, and constitutionalism: reflections on Evans $v$ Attorney General’ (2016) 75 C.L.J. 38.

${ }^{90}$ Thoburn v Sunderland City Council [2002] EWHC 195 (Admin.); [2003] Q.B. 151 at [63]; Craig, 'Constitutionalising constitutional law', p. 386.

${ }^{91} R$. (on the application of Anderson) $v$ Secretary of State for the Home Department [2002] UKHL 46; [2003] 1 A.C. 387 at [59] (Lord Steyn).

${ }^{92}$ Elettronica Sicula SpA. (ELSI) I.C.J. Rep. 1989 p. 15, 42 at [50] ('no doubt that the parties to a treaty can therein either agree that the local remedies rules shall not apply to claims based on alleged breaches of that treaty; or confirm that it shall apply. Yet the Chamber finds itself unable to accept that an important principle of customary international law should be held to have been tacitly dispensed with, in the absence of any words making clear an intention to do so'); R. O’Keefe, (2011) 81 B.Y.I.L. 339, 402.

${ }^{93}$ Territorial Jurisdiction of the International Commission of the River Oder P.C.I.J. Series A No. 23 (1929) p. 20 ('it would hardly be justifiable to deduce from a somewhat ill-chosen expression [contained in a treaty] an intention to derogate from a rule of international law so important as that relating to the ratification of conventions').

${ }^{94}$ Al-Jedda v United Kingdom (2011) 147 I.L.R. 107, (2011) 53 E.H.R.R. 23.

${ }^{95}$ Nada v Switzerland (2013) 56 E.H.R.R. 18.

${ }^{96}$ M. Andenas \& E. Bjorge, 'Human rights and acts by troops abroad' (2012) 18 E.P.L. 473, 485-7; R. Kolb, The Law of Treaties (Cheltenham 2016) 184.

${ }^{97}$ Al-Jedda v United Kingdom (2011) 147 I.L.R. 107, (2011) 53 E.H.R.R. 23 at [102].

${ }^{98}$ Nada v Switzerland (2013) 56 E.H.R.R. 18.
} 
was clearly prevented, by the language of the Security Council Resolution, from allowing the elderly and infirm Mr. Nada from entering or transiting thorough its territory. Switzerland had followed what it considered to be its obligation under the Charter of the United Nations; this meant that Nada was confined to living in Campione d'Italia, an exiguous Italian enclave within Switzerland, where his freedom of movement was severely restricted. Nonetheless, the Grand Chamber in Nada determined that, in spite of the clear language, it could not be assumed that the Security Council had meant for Switzerland to breach the rights of Nada in the way it had done; Article 8 of the Convention had been breached. ${ }^{99}$

The strong duty on the part of the courts flowing from s. 3 of the HRA now applies equally strongly to common law rights outside of the scope of the Human Rights Act. The position could also be thought to be confirmed at international law, where a similar principle has been developed in an almost identical manner.

\section{EXTERNAL EXIGENCIES}

\section{A. Common law rights, unlike Convention rights, are not set aside by the Charter of the United Nations}

The strength of common law rights emerges also in those post-HRA cases in which it has proven impossible to rely on Convention rights by reason of Article 103 of the Charter of the United Nations, according to which obligations under the Charter prevail over obligations under other agreements: 'In the event of a conflict between the obligations of the Members of the United Nations under the present Charter and their obligations under any other international agreement, their obligations under the present Charter shall prevail., ${ }^{100}$ Crucially, this includes, by virtue of Article 25 of the Charter, the obligation to 'carry out the decisions of the Security Council'. ${ }^{101}$ Given the increasingly active Security Council, more and more cases come before the courts in which 'legislative resolutions ${ }^{102}$ potentially breach the rights of individuals who are affected by the directions of the resolutions. This has come up in a number of cases in recent years. ${ }^{103}$

The important case of Al-Jedda $v$ Secretary of Defence, ${ }^{104}$ where the Appellate Committee of the House of Lords found that ECHR Article 5(1) was displaced by Security Council Resolution 1546 and Article 103, thus rejecting Al-Jedda's appeal, ${ }^{105}$ is not germane to this discussion as the answer to the question of 'whether English common law or Iraqi law applies to the appellant's detention' was determined in that case to be the latter. ${ }^{106}$

\footnotetext{
${ }^{99}$ Further: R. Kolb, 'L’article 103 de la Charte des Nations Unies’ (2013) 367 Hague Recueil 9, 116_ 44

10026 June 1945, 892 U.N.T.S. 119.

101 J Crawford, 'Chance, order, change: the course of international law' (2013) 365 Hague Recueil 9, 302 .

102 ibid 311-14.

103 e.g. $R$ (Global Witness) $v$ Secretary of State for Foreign and Commonwealth Affairs 14 September 2010, unreported (Q.B.) (Sales J.) p. 2 para. 1(c); Al-Jedda v Secretary of State for Defence [2010] EWCA Civ. 758; [2011] Q.B. 773; Al-Waheed v Ministry of Defence [2014] EWHC 2714 (Q.B.); [2014] EWHC 2714.

${ }^{104}$ Al-Jedda v Secretary of Defence [2007] UKHL 58; [2008] 1 A.C.

105 J. Crawford, State Responsibility: The General Part (Cambridge 2013), 200-2.

${ }^{106}$ Al-Jedda v Secretary of Defence [2007] UKHL 58; [2008] 1 A.C. at [4] \& [155] (Lord Bingham).
} 
The leading case is Ahmed $v$ H.M. Treasury, ${ }^{107}$ where the Supreme Court set out that Security Council resolutions would prevail over UK obligations under the ECHR, thus rendering nugatory the guarantees of the HRA in the context of the case. ${ }^{108}$ Instead the case raised the potential of conflict between the United Kingdom's obligations under international law according to the UN Charter to follow UN Security Council resolutions on the one hand and the principle of legality, in connection with what has been termed 'an extra-judicial confiscation scheme', ${ }^{109}$ on the other. Ahmed and the other appellants, all of whom were British citizens, had been designated under the Terrorism Order ${ }^{110}$ and the Al-Qaida and Taliban Order, ${ }^{111}$ the effect of which was the freezing of all their assets. They had been so designated because they had been listed by a UN Committee set up by the UN Security Council pursuant to Article 41 of the UN Charter. ${ }^{112}$ The United Kingdom gave effect to the UN Charter in domestic law through the United Nations Act 1946, of which Section 1 is in the following terms:

If, under article 41 of the Charter of the United Nations signed at San Francisco on 26 June 1945 (being the article which relates to measures not involving the use of armed force) the Security Council of the United Nations call upon His Majesty's Government in the United Kingdom to apply any measures to give effect to any decision of that Council, His Majesty may by Order in Council make such provision as appears to Him necessary or expedient for enabling those measures to be effectively applied, including (without prejudice to the generality of the preceding words) provision for the apprehension, trial and punishment of persons offending against the Order.

The UN Charter established the Security Council with a view, according to Article 24, 'to ensure prompt and effective action by the United Nations', conferring on it 'primary responsibility for the maintenance of international peace and security, and agree that in carrying out its duties under this responsibility the Security Council acts on their behalf.'

The question in Ahmed was what limits, if any, there were on the power conferred by Section 1 of the United Nations Act 1946 on the executive, and more specifically, 'whether the section confers power on the executive, without any Parliamentary scrutiny, to give effect in this country to decisions of the Security Council which are targeted against individuals'. ${ }^{113}$

It was especially the phrase 'necessary or expedient for enabling those measures to be effectively applied' which required judicial scrutiny. Lord Hope observed that the closer the measures at issue come to affecting what in Simms Lord Hoffmann described as the basic rights of the individual, the more exacting this scrutiny must become: 'If the rule of law is to mean anything, decisions as to what is necessary or expedient in this context cannot be left to the uncontrolled judgment of

\footnotetext{
${ }^{107}$ Ahmed v H.M. Treasury [2010] UKSC 2; [2010] 2 A.C. 534; Sedley, Lions under the Throne, 111; McLachlan, Foreign Relations Law, p. 109; A. Johnston \& E. Nanopoulos, 'The new UK Supreme Court, the separation of powers and anti-terrorism measures’ (2010) 69 C.L.J. 217.

${ }^{108}$ Ahmed v HM Treasury [2010] UKSC 2; [2010] 2 A.C. 534 at [106] (Lord Phillips); [184] (Lord Rodger); [238] (Lord Mance).

109 Sedley, Lions under the Throne, p. 111.

110 Terrorism (United Nations Measures) Order 2006.

${ }^{111}$ Al-Qaida and Taliban (United Nations Measures) Order 2006.

112 S.C. Res. 1267 (15 October 1999).

${ }^{113}$ Ahmed v H.M. Treasury [2010] UKSC 2; [2010] 2 A.C. 534 at [44] (Lord Hope).
} 
the executive. ${ }^{114}$

In Lord Hope's view, '[t]he undoubted fact that section 1 of the 1946 Act was designed to enable the United Kingdom to fulfill its obligations under the Charter to implement Security Council resolutions does not diminish this essential principle.' This was due to the fact that the resolutions in issue were the product of a body of which the executive is a member as the United Kingdom's representative. Not only would it be unacceptable to confer on the executive an unlimited discretion as to how those resolutions, which it has a hand in making, were to be implemented; it would conflict with 'the basic rules that lie at the heart of our democracy'. ${ }^{115}$

The measures in question were struck down as being 'a clear example of an attempt to adversely affect the basic rights of the citizen without the clear authority of Parliament'; 'fundamental rights cannot be overridden by general or ambiguous words'. ${ }^{116}$ Ahmed thus exemplifies that, in post-HRA cases where reliance on the HRA has been impossible due to external exigencies but where English common law could be relied on, the Supreme Court has been fastidious in upholding fundamental rights which are protected at common law, even ordinary property rights. This takes us to the next theme, which concerns the considerable - perhaps even ironic openness of autochthonous common law rights to general international law, that is, to customary international law. ${ }^{117}$

\section{B. Common law rights, more easily than Convention rights, give effect to general international law}

The customary international law of human rights will apply by operation of the rule according to which customary international law is 'observed and enforced ... as part of the common law'; ${ }^{118}$ or, as Lord Mance put it in Keyu, there is a presumption that customary international law,

once established, can and should shape the common law, whenever it can do so consistently with domestic constitutional principles, statutory law and common law rules which the courts can themselves sensibly adapt without it being, for example, necessary to invite Parliamentary intervention or consideration. ${ }^{119}$

Interestingly, in the case of Keyu, which specifically concerned HRA rights and the right to inquests of historic killings, the Supreme Court held that it would not be right for the court to rely on the purported customary international law principle at issue because Parliament had, through legislation, 'effectively pre-empted the whole area of

\footnotetext{
114 ibid at [45].

115 ibid.

116 ibid at [61].

${ }^{117}$ H. Kelsen, Principles of International Law (New York 1952), p. 188 (which explains that general international law means customary international law).

${ }^{118}$ R. v Metropolitan Stipendiary Magistrate, Ex p. Pinochet Ugarte (No. 1) [2000] 1 A.C. 61, 89-90 (Lord Lloyd); R. v Metropolitan Stipendiary Magistrate, Ex p. Pinochet Ugarte (No. 3) [2000] 1 A.C. 147, 276 (Lord Millett); Beatson and others, Human Rights, 18-19; cf. the more cautious model set ot in P. Sales \& J. Clement. 'International law in domestic courts: the developing framework' (2008) 124 L.Q.R. 388.

${ }^{118}$ Dickson, Human Rights, 20-36, esp. p. 31.

${ }^{119}$ Keyu v Secretary of State for Foreign \& Commonwealth Affairs [2015] UKSC 69; [2015] 3 W.L.R. 1665 at [150] (Lord Mance).
} 
investigations into historic deaths' ${ }^{120}$ In such circumstances domestic courts cannot or should not recognise or import a principle which would be wider and would extend to cover events further back in time than would be covered by the inquiries provided by such legislation and/or by the ECHR. ${ }^{121}$ Keyu could thus stand as an example of how difficult it can be to weave into Convention rights the customary international law of human rights.

Conversely, in the development of the common law the courts can and should, as the Supreme Court observed in Osborn, take account of the United Kingdom's international obligations. ${ }^{122}$ As Beatson and others have pointed out, customary international law is a potentially important source of the common law, because it includes 'some norms which are relevant to human rights and which, therefore, may be regarded as part of the common law'. ${ }^{123}$ In fact, given the thickening and widening of international law over recent decades, the United Kingdom's obligations under customary international law include a great number of rules providing rigorous protection of human rights; in some cases the protection is even stronger than that which is afforded by incorporated treaty obligations such as those under the ECHR.

In order to determine the existence and content of a rule of customary international law, it is necessary to ascertain whether there is a general practice that is accepted as law. ${ }^{124}$ In spite of increasing and widespread codification at the international plane, customary international law remains an important formal source of international law. ${ }^{125}$ Where primary rules of conduct are now regulated by treaty, they do not necessarily subsume and supervene parallel customary rules. ${ }^{126}$ As the International Court of Justice observed in Nicaragua, even where the customary norm and the treaty norm have exactly the same content, this is not a reason to hold that the incorporation of the customary norm into treaty law 'must deprive the customary norm of its applicability as distinct from that of the treaty norm'. ${ }^{127}$

Some rights under international law still accrue only to aliens; others, being human rights, accrue to all individuals, regardless of nationality. As a distinguished Tribunal observed in Biloune, which concerned the rights of a Syrian investor who had suffered maltreatment at the hands of the Ghanaian government:

Long-established customary international law requires that a State accord foreign nationals within its territory a standard of treatment no less than that prescribed by international law. Moreover, contemporary international law recognizes that all individuals, regardless of nationality, are entitled to fundamental human rights (which, in the view of the Tribunal, include property as well as personal rights), which no government may violate. ${ }^{128}$

The courts of other countries seem to have gone further than the UK courts in relying on the customary international law of human rights. Examples include the Belgian Commercial Court, in connection with the right to peaceful enjoyment of one's

\footnotetext{
120 ibid at [151] (Lord Mance).

121 ibid at [151].

122 e.g. R. (Osborn) v Parole Board [2013] UKSC 61; [2014] A.C. 1115 at [57] (Lord Reed).

${ }^{123}$ Beatson and others, Human Rights, p. 18.

124 art. 38(1)(b), Statute of the International Court of Justice, 26 June 1945, 892 U.N.T.S. 119.

${ }^{125}$ P. Tomka, 'Custom and the International Court of Justice' (2013) 12 L.P.I.C.T. 195, 196.

126 ibid.

${ }^{127}$ Military and Paramilitary Activities in and against Nicaragua, I.C.J. Rep. 1986, 93-5 at [175][177].

${ }^{128}$ Biloune v Ghana (1989) 95 I.L.R. 183, 203 (Judge Scwebel, President; Wallace; Leigh, Arbitrators).
} 
property in ACSYNGO; ${ }^{129}$ the Austrian Supreme Court, in connection with fair trial rights in Service of Summons in Criminal Proceedings; ${ }^{130}$ the German Federal Constitutional Court, in connection with the right to marriage in the Basic Right to Marry Case; ${ }^{131}$ the Italian Constitutional Court, in connection with the right of foreigners not to be subjected to military duty in their country of residence in Judgment no. 278 of 1992; ${ }^{132}$ and the Australian High Court, in connection with racial discrimination in Koowarta $v$ Bjelke-Pedersen. ${ }^{133}$

It is indisputable that many human rights obligations now apply as customary international law. ${ }^{134}$ The customary international law of human rights (in common with the ECHR $)^{135}$ consists of norms expressed at a high level of generality. This reflects the nature of customary international law more generally; as a Chamber of the International Court of Justice once observed, '[a] body of detailed rules is not to be looked for in customary international law' ${ }^{136}$ The rules of the customary international law of human rights, like those of the ECHR, therefore have to be fulfilled at the domestic level through a substantial body of more specific domestic law.

Little has been written on this particular topic. ${ }^{137}$ In order to make out that a number of human rights obligations do in fact apply as principles of customary international law, four examples will be given: the customary international law against arbitrary detention, the customary international law protection against non refoulement, the customary international law rules against unlawful expulsion, and the customary international law protection of property rights.

First, in relation to arbitrary detention, there is no doubt that general international law protects this right, whether it involves aliens or nationals. In the 1980s the Restatement (Third) of the Foreign Relations Law of the United States provided that '[a] state violates international law if, as a matter of state policy, it practices, encourages, or condones prolonged arbitrary detention'. ${ }^{138}$ The UN Human Rights Committee has observed that the right not to be arbitrarily arrested or detained was among the 'provisions in the Covenant that represent customary international law'; ${ }^{139}$ the UN Working Group on Arbitrary Detention, in the United Nations Basic Principles and Guidelines on Remedies and Procedures on the Right of Anyone Deprived of their Liberty to Bring Proceedings before a Court, observed that the right not to be arbitrarily detained has found expression as a 'general practice accepted as law, constituting customary international law'. ${ }^{140}$ Against this background, the Tribunal in Arctic Sunrise referred to the right not to be arbitrarily detained as being

\footnotetext{
${ }^{129}$ ACSYNGO v Compagnie de Saint-Gobain (1986) 82 I.L.R. 127, 130-7.

130 Service of Summons in Criminal Proceedings (1969) 38 I.L.R. 133, 135.

${ }^{131}$ Basic Right to Marry Case (1971) 72 I.L.R. 295, 298.

132 Judgment no. 278 of 1992 at [2].

133 Koowarta v Bjelke-Pedersen (1982) 68 I.L.R. 181, 208-11, 221-4 \& 235-6.

${ }_{134}$ R. Jennings \& A. Watts, Oppenheim's International Law Vol 1 9th ed, (London 1992), p. 1000.

${ }^{135}$ R. (Osborn) v Parole Board [2013] UKSC 61; [2014] A.C. 1115 at [55]-[56] (Lord Reed).

136 Gulf of Maine, Judgment I.C.J. Rep. 1984 p. 246, 299 at [111].

137 See, however, B. Conforti, 'National courts and the international law of human rights' in B. Conforti \& F. Francioni (eds.), Enforcing International Human Rights in Domestic Courts (The Hague 1997), 3-4.

${ }^{138}$ Restatement (Third) of the Foreign Relations Law of the United States (1986) at [702(e)].

139 General Comment No. 24: Issues Relating to Reservations Made upon Ratification or Accession to the Covenant of the Optional Protocols thereto, or in Relation to Declarations under Article 41 of the Covenant, 4 November 1994, U.N. doc. CCPR/C/21/Rev.1/Add.6 at [8].

${ }^{140} 6$ July 2015, A/HRC/30/37 at [11].
} 
amongst the 'rules of customary international law'. ${ }^{141}$ In Diallo the International Court of Justice stated, in relation to Mr. Diallo's arbitrary detention at the hands of Congolese authorities, that it followed from treaty obligations applying in the case that '[a]ll persons deprived of their liberty shall be treated with humanity and with respect for the inherent dignity of the human person'. ${ }^{142}$ The Court added that there is no doubt that the prohibition of inhuman and degrading treatment 'is among the rules of general international law which are binding on States in all circumstances, even apart from any treaty commitments'. ${ }^{143}$

Second, in relation to non-refoulement, the essence of which is that a State may not oblige a person to return to a territory where he may be exposed to persecution, it now widely agreed that the principle is regarded as a principle of customary international law. ${ }^{144}$ Thus in Ngassam v Republic of Cyprus the Supreme Court of Cyprus observed that everyone has the right to seek and enjoy asylum from persecution in other countries, and that 'under customary international law, States cannot, in accordance with the principle of non-refoulement, return a refugee to a country where she or he faces persecution'. ${ }^{145}$ In Soering $v$ United Kingdom the European Court of Human Rights observed in connection with non-refoulement that Article 3 is 'generally recognised as an internationally accepted standard'; ${ }^{146}$ according to the Swiss Federal Department of Foreign Affairs the customary international law right is coterminous with the extraterritorial application of the nonrefoulement right protected under Article 3 of the ECHR. ${ }^{147}$ The non-refoulement principle at customary international law may be stated as providing, without limitation or exception, that no person shall be rejected, returned, or expelled in any manner whatever where this would compel him or her to remain in or return to a territory where substantial grounds can be shown for believing that he or she would face a real risk of being subjected to torture or cruel, inhuman or degrading treatment of punishment. ${ }^{148}$

Thirdly, so far as concerns expulsion, customary international offers strong protection of this right; indeed, there is evidence to suggest that general international law goes further than the European Convention. Article 1 of Protocol 7 to the ECHR provides protection only of procedure, not of substance, ${ }^{149}$ that is, not relating to the grounds on which expulsion might be sought. Customary international law, however, has since the beginning of the twentieth century laid down certain minimum requirements as to the reasons adduced for expulsion. Thus already in 1903 the Tribunal in Boffolo determined that whilst a State under international law possesses a general right of expulsion, expulsion 'should only be resorted to in extreme instances,

\footnotetext{
${ }^{141}$ Arctic Sunrise (The Netherlands v Russia) Award on the Merits, 14 August 2015, P.C.A. Case No. 2014-02 at [197]-[198].

${ }^{142}$ Ahmadou Sadio Diallo (Guinea v Congo) I.C.J. Rep. 2010 p. 639, 671 at [87]; noted: M. Andenas, (2011) 60 I.C.L.Q. 810; E. Bjorge, (2011) 105 A.J.I.L. 534.

143 ibid; United States Diplomatic and Consular Staff in Tehran ICJ Rep 1980 p. 3, 42 at [91].

${ }^{144}$ E. Lauterpacht \& D. Bethlehem, 'The scope and content of the principle of non-refoulement' in E. Feller and others (eds.), Refugee Protection in International Law (Cambridge 2003) p. 149; UN High Commissioner for Refugees (UNHCR), The Principle of Non-Refoulement as a Norm of Customary International Law, 31 January 1994 at [3].

145 Ngassam v Republic of Cyprus (2010) 156 I.L.R. 371, 380 at [129].

146 Soering $v$ United Kingdom (1989) 98 I.L.R. 270 at [88].

147 (1994) 4 Revue suisse de droit international et de droit européen 601, 601-3

${ }^{148}$ Lauterpacht \& Bethlehem, 'The principle of non-refoulement', p. 163.

${ }^{149}$ Bolat v Russia (2008) 46 E.H.R.R. 18 at [81]-[83]; Lupsa v Romania (2008) 46 E.H.R.R. 36 at [54]-[61]; Ahmadou Sadio Diallo I.C.J. Rep. 2010 639, 719 (Joint Declaration of Judges Keith \& Greenwood); E. Bjorge, (2011) 105 A.J.I.L. 534, 539-40.
} 
and must be accomplished in the manner least injurious to the person affected'; '[t]he country exercising the power [of expulsion] must when occasion demands, state the reason of such expulsion before an international tribunal, and an inefficient reason or none being advanced, accept the consequences.' ${ }^{150}$ In the more recent case of LAFICO $^{151}$ Burundi, had expelled two Libyan nationals. The Tribunal determined that 'any collective expulsion makes it practically impossible to secure respect for the guarantees which must normally accompany expulsions if they are to be lawful'. It went on to state that: '[t]he State in question must establish the reality of the situation and state those elements establishing "reasonable cause" for expulsion'. ${ }^{152}$ Whilst diplomats can be expelled almost willy-nilly, ${ }^{153}$ 'the expulsion of aliens in general must be based on a just reason and on reasonable factual grounds, taking account of the degree of discretion granted to a State taking such a measure'. ${ }^{154}$ It may be this background of general international law that encouraged the International Court of Justice in Diallo to go substantially further than human rights treaty bodies, including the European Court, in interpreting conventional human rights provisions on expulsion. ${ }^{155}$

Fourthly, in relation to property, there can be no doubt that certain aspects of the protection of property is stronger under customary international law than it is under the European Convention. Under the ECHR, the claimant is rarely, if ever, fully compensated when his or her property has been lawfully expropriated by the State. ${ }^{156}$ Thus the Tribunal in Bank for International Settlements - Partial Dispute with Former Private Shareholders observed that 'it is true that the jurisprudence of the European Court of Human Rights has adopted a flexible standard, described as one of "appropriate" compensation for taking by a state of the property of its nationals'; but 'the general relevance of Human Rights law aside, the mainstream of general international law', the Tribunal observed, 'has required full compensation'. ${ }^{157}$ This standard means that no less that the full market value of the property must be compensated. As the US-Iran Claims Tribunal observed in Sedco v Iran, there is overwhelming support for the conclusion 'that under customary international law in a case such as here presented - a discrete expropriation of alien property - full compensation should be awarded for the property taken'; '[t]his is true whether or not the expropriation was otherwise lawful'. ${ }^{158}$ Indeed, it is clear from the practice of international courts and tribunals that this is the position customary international law has taken since at least the 1920 s. $^{159}$

Given the openness of the common law to the obligations of the United Kingdom under general international law, and the fact that the customary

\footnotetext{
150 Boffolo Case (1903) 10 R.I.A.A. 528, 537.

${ }^{151}$ LAFICO v Burundi (1991) 96 I.L.R. 279.

152 ibid 313.

153 art. 9, Vienna Convention on Diplomatic Relations, 18 April 1961, 500 U.N.T.S. 95.

${ }^{154}$ LAFICO v Burundi (1991) 96 I.L.R. 279, 313.

${ }^{155}$ Ahmadou Sadio Diallo I.C.J. Rep 2010 639, 663-4 at [65]-[68] \& 719 (Joint Declaration of Judges Keith and Greenwood); E. Bjorge, (2011) 105 AJIL 534, 539-40.

156 A. Pellet, 'Notes sur la "fragmentation" du droit international: droit des investissement internationaux et droits de l’homme’ in Unité et diversité du droit international (The Hague 2014), 777-8.

157 Bank for International Settlements - Partial Dispute with Former Private Shareholders (Partial Award) (2002) 23 R.I.A.A. 153, 231 at [168].

158 Sedco v Iran (1987) 84 I.L.R. 527.

${ }^{159}$ M. Mendelson, 'Compensation for expropriation' (1985) 79 A.J.I.L. 414, 415-18; Administrative Decision No. III (1923) 7 R.I.A.A. 64, 65-6; Goldenberg (1928) 2 R.I.A.A. 901, 909; (1928) 4 I.L.R. 542, 545; De Sabla (1934) 28 A.J.I.L. 602, 611-12; Liamco v Libya (1977) 62 I.L.R. 210-11.
} 
international law of human rights remains largely unexplored in this context, there is a rich vein to be mined by the UK courts as they 'take account of those obligations in the development of the common law'. 160

\section{CONCLUSION}

The problems connected with the normative reach of common law protections of fundamental rights are less far reaching than has been argued by some. Equally, the protective rigour accorded to common law rights has a greater potential than has hitherto been recognised. In certain types of case, the non-legislative character of common law rights is a strength rather than a weakness, as common law rights are not set aside by the UN Charter. And, although based on the idea of autochthony, common law rights can more easily than Convention rights tap into the potentially very rich resource of the customary international law of human rights. Thus common law rights can overcome what has been perceived to be the domestic law infirmities attaching to them and negotiate the shoals of autochthony by means of the common law's openness to international influences. Domestic and international exigencies combine to mean that, if given their proper due, common law rights have a very promising future indeed.

${ }^{160}$ R. (Osborn) v Parole Board [2013] UKSC 61; [2014] A.C. 1115 at [57] (Lord Reed). 